\title{
CONCEPTS OF SOIL FORMATION AND CLASSIFICATION IN ARCTIC REGIONS*
}

\author{
J. C. F. Tedrow and J. E. Cantlont
}

\section{Introduction}

ome eighty years ago, when Dokuchaev (Margulis, 1954) distinguished $D$ five natural soil zones - tundra, podzol, chernozem, desert, and laterite - the stage was set for a systematic study of soils as naturally occurring bodies. Of these, the tundra has received by far the least attention. European investigators, notably the Russians, have made many studies of the northern regions but in North America few reports of scientific studies in the Arctic have been made by trained soil scientists. In this paper some relationships of soil-forming processes operating in the various northern regions, especially in connection with the podzolic and the so-called tundra processes, are presented; and some problems in connection with vegetationsoil relationships and the classification and mapping of soils are outlined.

In the formation of soil the most important factors that have to be taken into consideration are climate, parent material, biotic elements, relief, and time. The interaction of these five factors, operating at different intensities will produce soils with different properties. Given sufficient time, adequate drainage and depth of mineral material on the more level, stable landforms, a mature or zonal soil will tend to form. In the tropics the zonal soils will have a reddish appearance, in the prairies a dark brown to black, whereas in the northern forested regions the upper mineral horizons will have a bleached appearance. Distinct as these zonal soils are, they have at least one important feature in common, that is, they form under conditions of adequate drainage. Tundra soils, however, form under conditions of poor drainage and it may be somewhat fallacious to speak of them in terms of zonal soils as is done with podzols and chernozems.

\section{Soil processes in the northern forest and tundra regions}

Tundra (Tedrow et al. 1958) soils are those widespread, poorly drained soils of the arctic regions that are mineral in character and underlain by

* Journal Series paper of the New Jersey Agr. Exp. Sta., Rutgers University, the State University of New Jersey, Department of Soils; and Publication No. 58-4 of the Department of Botany, Michigan State University.

$\dagger$ Department of Soils, Rutgers University; and Department of Botany and Plant Pathology, Michigan State University, respectively. 
permafrost. Partly water-logged conditions and glei-ing are usually present in the upper mineral horizons. The organic horizon at the surface is usually several inches thick and upper horizons tend to be strongly acid in reaction. Upland tundra soils, while poorly drained, occupy the higher sites on sloping land and rounded hilltops. Meadow tundra soils occupy the lower positions, the flatter areas, and situations of very poor drainage. The pioneer work of Dokuchaev, Sibirtzev, Afanasiev, and others provided for the recognition of tundra soil in idealized, global classification diagrams. Sibertzev (Glinka, 1928; Margulis, 1954), designated tundra soil as a zonal soil in the 1890's; however, because of the paucity of information existing on tundra soils at that time he did little more than make provision for it in his schematic diagram. Marbut (1927) in his proposal categorizing major kinds of soils recognized the tundra soil as a normal soil of the cold zone just as he did the podzol, chernozem and laterite in other climatic zones. He stated:

"The normal profile. Experience has shown that in every region having what may be defined as normal relief, there is a normal soil profile. By normal relief is meant the relief that at the present time characterizes the greater part of the earth's surface, and for the purpose of this discussion, may be described as smooth, undulating or rolling, with the relation to drainage such that the permanent water-table lies entirely below the bottom of the solum."

Further, in his discussion of immature soils, Marbut (1928) states:

". . . another factor which causes some of the soils of a given region to be immature in their development is that of poor drainage. Mature soils attain maturity only under the influence of normal, good drainage. Excessive amounts of water and especially a high water-table or high ground-water prevent the development of a complete, normal profile."

Unquestionably the soil profiles that have been long recognized as tundra form under conditions of poor drainage (Neustruev, 1927). The tundra profile shows all the characteristics of gleization, and free water is commonly present up to the surface of the soil. This wet condition is greatly influenced by the presence of permafrost, usually at depths of from 1 to 2 feet. Although soil scientists point out that a zonal or mature soil can form only under conditions of free drainage, they nevertheless state that tundra soil is a zonal soil. This direct contradiction that originated over a quarter of a century ago should be done away with.

It has been suggested that it would be more appropriate to designate tundra soil as an intrazonal (hydromorphic) rather than a zonal soil (Gorodkov, 1939; Robinson, 1949; Tedrow et al., 1958).

A number of qualitative soil-forming processes operate in the several climatic regions of the earth, such as those of laterization and podzolization. These processes tend to be intensified or weakened along climatic gradients. Unfortunately, some writers imply that the podzolic process gives way northward to a special tundra soil-forming process unique to the arctic regions; or that a weak podzolic process is operating in tundra soils. Neither of these concepts is supported by facts. 
Much of the misunderstanding results from the futile attempt to relate a podzol, which forms under conditions of free drainage, to a tundra soil, which forms under conditions of highly impeded drainage. A more orderly picture of relationships emerges when one compares the mature soils in the northern podzol zone with mature soils locally found in the arctic regions on well-drained sites, and the so-called tundra soils with the northern forested glei soils.

North of the zone of maximum podzolization, the podzolic process weakens but does not grade into a special type of soil formation unique to the arctic regions (Gorodkov, 1939; Tedrow et al., 1958). Instead, it continues to operate on the well-drained, stable sites (Fig. 1). As mean summer temperatures become lower and precipitation decreases, the process operates at a very much reduced intensity. But it is of sufficient magnitude to bring some mineral elements into solution. These apparently recombine with the organic residues to produce the brown colour in the upper horizon. Leaching is very feeble, and no visual evidence of translocation of mineral elements is normally noted in the profile. Meinardus (1930) describes some weak processes operating in the well-drained shallow soil areas of Spitsbergen that involve leaching of divalent cations and conversion of some $\mathrm{FeO}$ to $\mathrm{Fe}_{2} \mathrm{O}_{3}$. Leahey (1949) mentions reddish-brown forested soils of the Yukon Territory outside the permafrost region and mineral soils within it that have a thin, reddish-brown solum. Kellogg and Nygard (1951) report subarctic brown forest soils of central and southern Alaska with various yellow and brown sola.

Arctic brown are those soils of the arctic regions that are mineral in character and form under free drainage. Their areal extent is small and is confined primarily to escarpment areas, ridges, terrace edges, and stabilized dunes. The upper mineral horizon approximates a dark-brown colour and is acid in reaction. Colours grade through various yellow-browns and greybrowns with depth. The active layer is usually deep. Arctic brown soil has been reported in Alaska north of the 71st parallel (Tedrow and Hill, 1955). In this soil the podzolic nature is so weakly developed that it can be detected only by chemical and mineralogical techniques (Drew and Tedrow, 1957). Pierre Dansereau (personal communication) supplied the authors with samples and descriptions of soils from Baffin Island that correspond to those of the arctic brown soils. This suggests that the brown soils are also present in the Eastern Canadian Arctic. At higher altitudes in the Arctic, as in the Brooks Range, the soil-forming process in the well-drained sites becomes so feeble that it is questionable whether it actually should be designated as a process. The solum in well-drained areas may be only a few inches thick. These soils resemble those assigned to polar desert by Gorodkov (1939).

Just as the very local brown surface soils of the Arctic are a northern counterpart of the podzols, so the widespread tundra soils, forming under impeded drainage, are a northern counterpart of the glei soils of the northern forested regions (Fig. 1). Northward of the forested areas the impermeable permafrost layer is close to the surface; this results in a very 
Fig. 1. Podzols grade northward into arctic brown and related soils, whereas glei soils grade into tundra. The graphic generalization indicates that northward the tundra and bog soils become dominant areally, whereas arctic brown soil is present only in small, localized areas (Lithosols excluded).

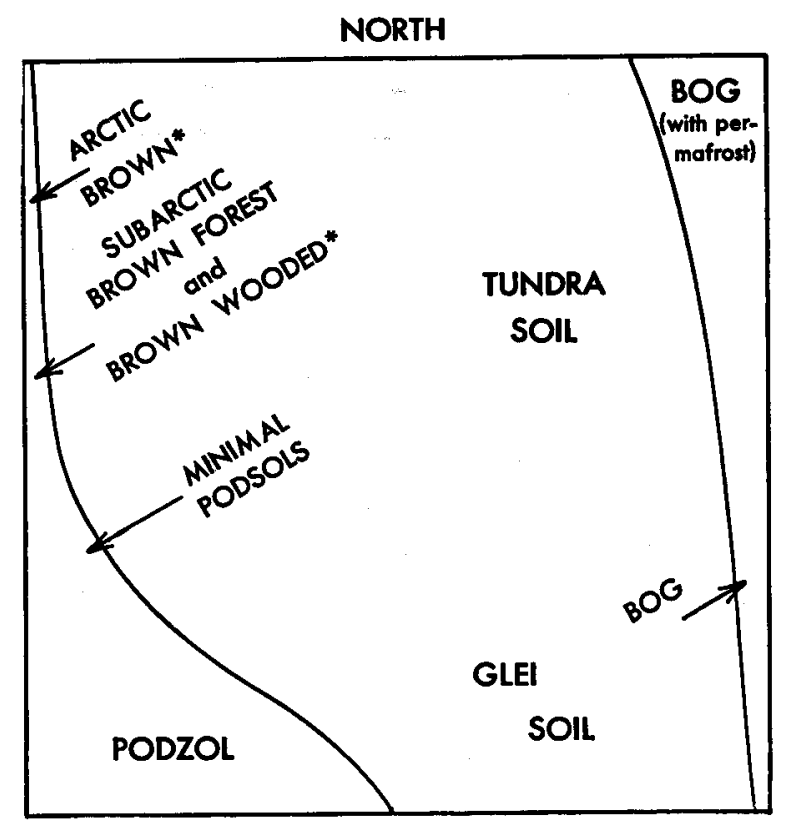

* Permafrost is usually deep and apparently has only minor influence on soil features.

high proportion of poorly drained land. The process of gleization, although operating on great expanses, weakens in northern areas because of the reduced chemical and biological activity, short growing season, and low temperature.

In both wet and well-drained sites downslope movement combines with frost processes, tending to disrupt any orderly morphology. This downslope movement increases with steepness of slope. On slopes of 3 to 5 per cent downslope movement of soil does not appear to be a major factor. But as slopes increase to the 20 to 40 per cent level the process becomes intense. These disturbances manifest themselves in an erratic appearance of the soil profile and indirectly by the unique surface characteristics of the landscape (Washburn, 1956; Sigafoos and Hopkins, 1952) and related evidence (Figs. $2,3,4$, and 5 ).

Apparently, frost processes cause a certain amount of physical displacement of the mineral and organic matter. Despite the volume of descriptive literature available on the subject of frost action, virtually no quantitative measurements on rates of displacement and movement of soils are available. Until they are, one can only speculate as to the rate at which the cryopedologic processes operate. On the better-drained glei soils, such as those of the higher and gently sloping terrains, the processes of soil formation operate at an intensity sufficient for a number of genetic properties to become evident in the profile. The upper horizons display more yellow-brown and related colours near the surface, grading into duller colours with depth. 


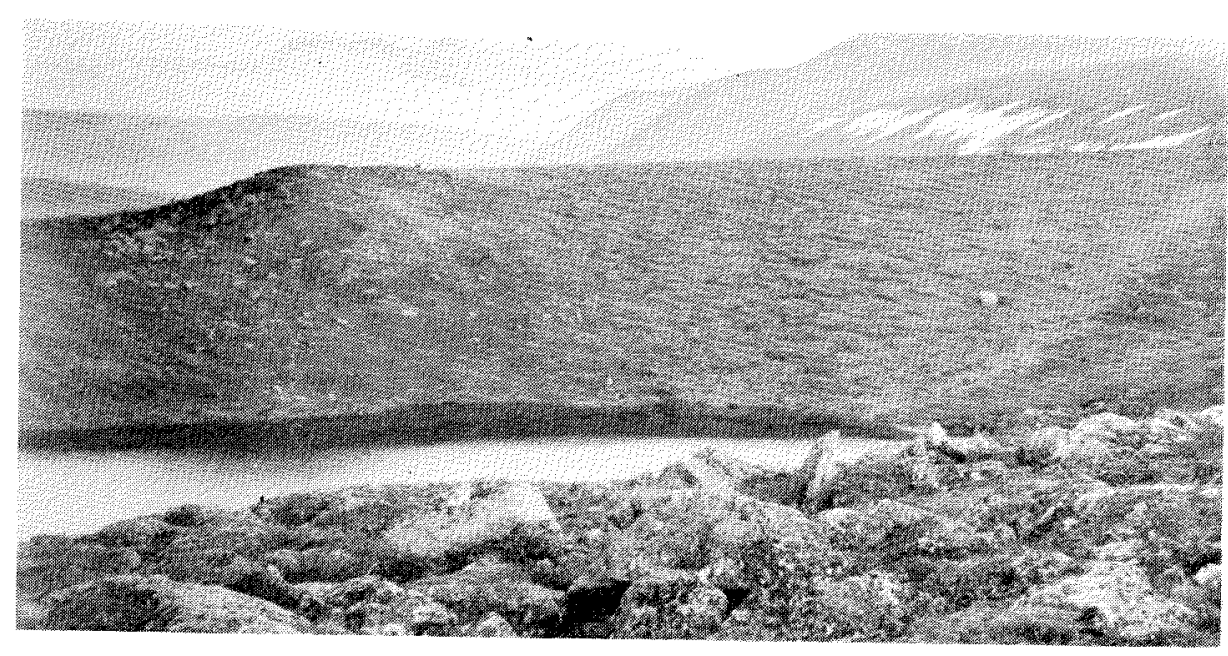

Fig. $z_{*}$

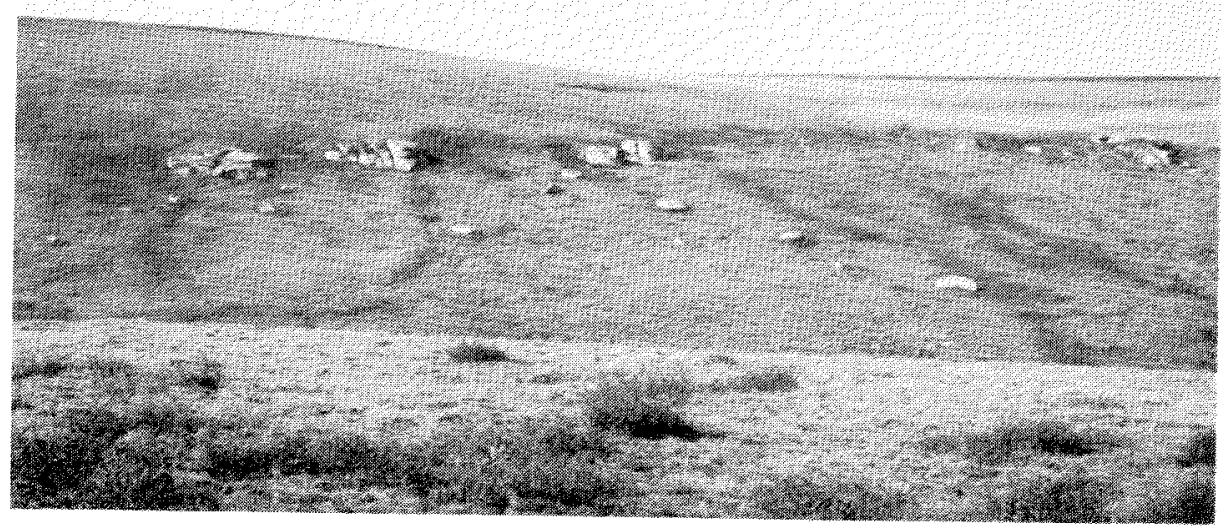

Fig. 3.

If cryopedologic processes were operating at a rapid rate in these soils, colour differences would not be detected between the various upper horizons and a more homogeneous colour would be present throughout the active zone.

If the soils and soil formation processes in the arctic tundra region are examined and compared with their counterparts of temperate regions, we find that the mature, normal soil (in the sense of Marbut and earlier European investigators) is not the most extensive. The profiles of these highly local arctic brown soils reflect the full impact of the regional climate, unmodified by waterlogged conditions or major frost displacement. If one chooses to equate zonality with these former unmodified conditions, then 


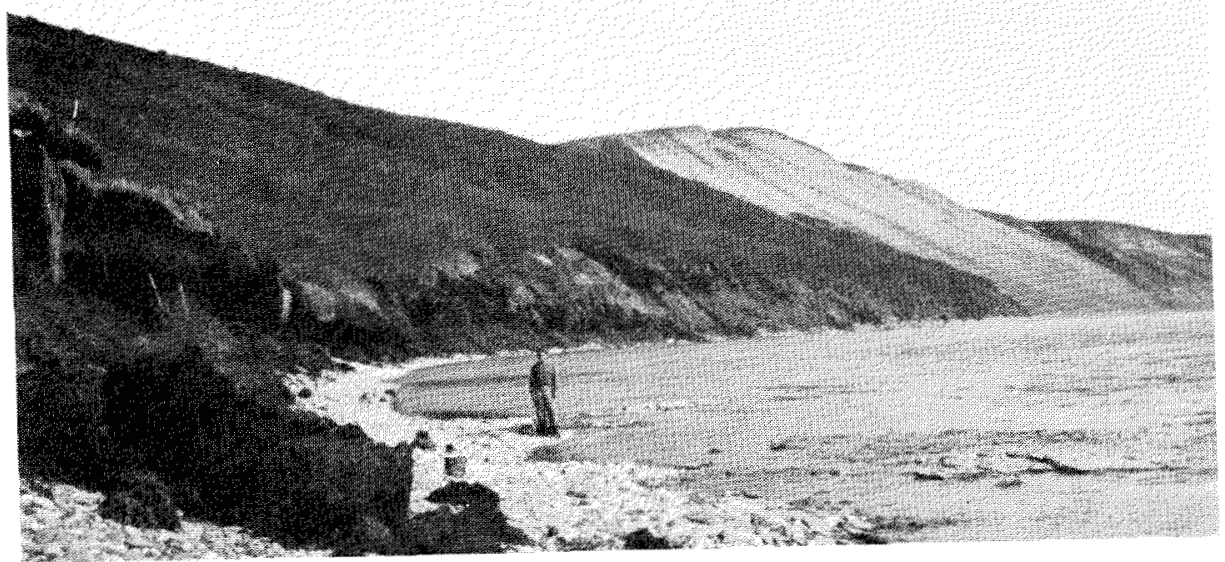

Fig. 4 .

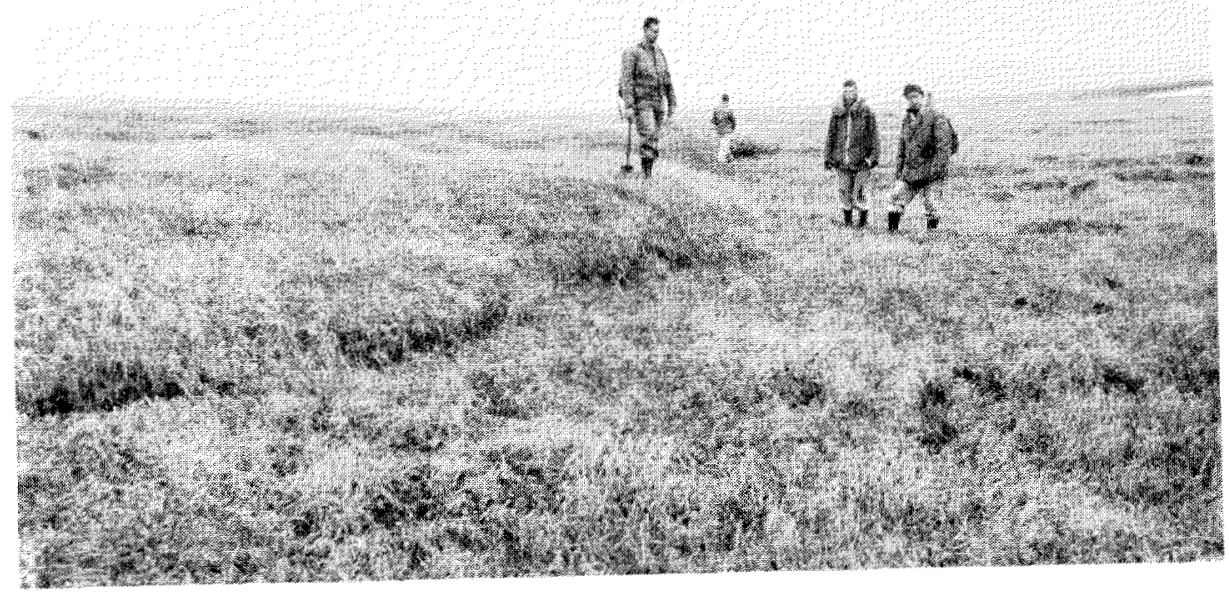

Fig. 5 .

Figs. 2-5. Some features indicating instability of soils on the steeper terrain are the presence of (Fig. 2.) lobate terraces near the Jago River about 10 miles north of McCall Glacier; (Fig. 3) rock broken off the outcrop and moved downslope near Umiat, Alaska; (Fig. 4) highly disturbed soil profiles resulting from solifluction processes (the debris at the foot of the slope exceeds 20 feet in thickness), photo taken along the Colville River with Mt. Umiat in the background; and (Fig. 5) solifluction lobe covering part of a terrace, photo taken near the Pitmega River 40 miles east of Cape Lisburne.

tundra soils should not be considered zonal. To assign zonal status to tundra soils equates zonality with simple regional dominance. The implied idea that the zonal profile fully reflects the impact of the regional climate must then be abandoned. On tundra soils we have the unusual circumstance that 
the operation of the regional climate brings about its own suppression as a soil-forming factor through the formation of the impervious frozen layer. Here minor regional differences of climate have much less effect on the soil pattern than local micro-variations in drainage.

\section{Vegetation-soil relationships, micro-relief, and soil classification problems}

Relation between soil type and vegetation. In the Arctic, as well as in most other climatic regions, the moisture status of the soil exerts a marked selective influence on the plant populations. Thus, when on the basis of profile morphology the soils of arctic Alaska are arranged into a sequence (Fig. 6), representing a drainage catena (Tedrow et al., 1958), the associated vegetation normally shows a characteristic sequence of communities (Fig. 7). On the deep and the shallow well-drained soils, the regularity in soil-vegetation relationships, although by no means perfect, is pronounced. As the soils forming under free drainage grade to progressively more shallow ones, as in areas peripheral to rock outcrops or where the mineral substrate changes into one of unusually coarse texture, the Upland Meadow communities have less total coverage and harbour more xeric species. This trend ultimately replaces the Meadow types with Barrens types, with less than half the surface covered. Given the soil profile and the general location on the Alaskan Arctic Slope, it is possible to predict the vegetation type with a fair degree of reliability.

On soils formed under restricted drainage a somewhat more difficult problem of soils and vegetation relationships exists. Field observations show without question that on tundra and bog soils a spectrum of plant communities exists that ranges from those dominated by species associated with well-drained sites to those dominated by species associated with very wet sites (Fig. 7) (Cantlon and Gillis, 1957). Thus, on that portion of the catena occupied by the tundra and bog soils the reliability of predicting plant-soil relationship is poorer.

To help illustrate this situation, we may compare it with better-known vegetation-soil relationships. We find that in the moist temperate region natural vegetation is useful in inferring the stages of drainage in the soil catena. It must be remembered, however, that such correlation is used for the most part with mineral soils, and very little work has been done with the vegetation differences on various organic soils. With organic soils in arctic Alaska, local differences in moisture levels produce differences in vegetation. This is true in a lower degree in the more rainy temperate region, but the total area of the drier fragments is usually insignificant. Further, in the temperate region the presence of forest lends a more homogeneous appearance, the tree layer more or less completely subjugating any micro-patterning in the understory. In the treeless Arctic, where various cryopedologic processes operate to give pronounced microrelief, vast areas of tundra and bog soils exhibit patterns or mosaics of vegetation (Spetzman, 1951; Wiggins, 1951; Sigafoos, 1952; Churchill, 1955; 


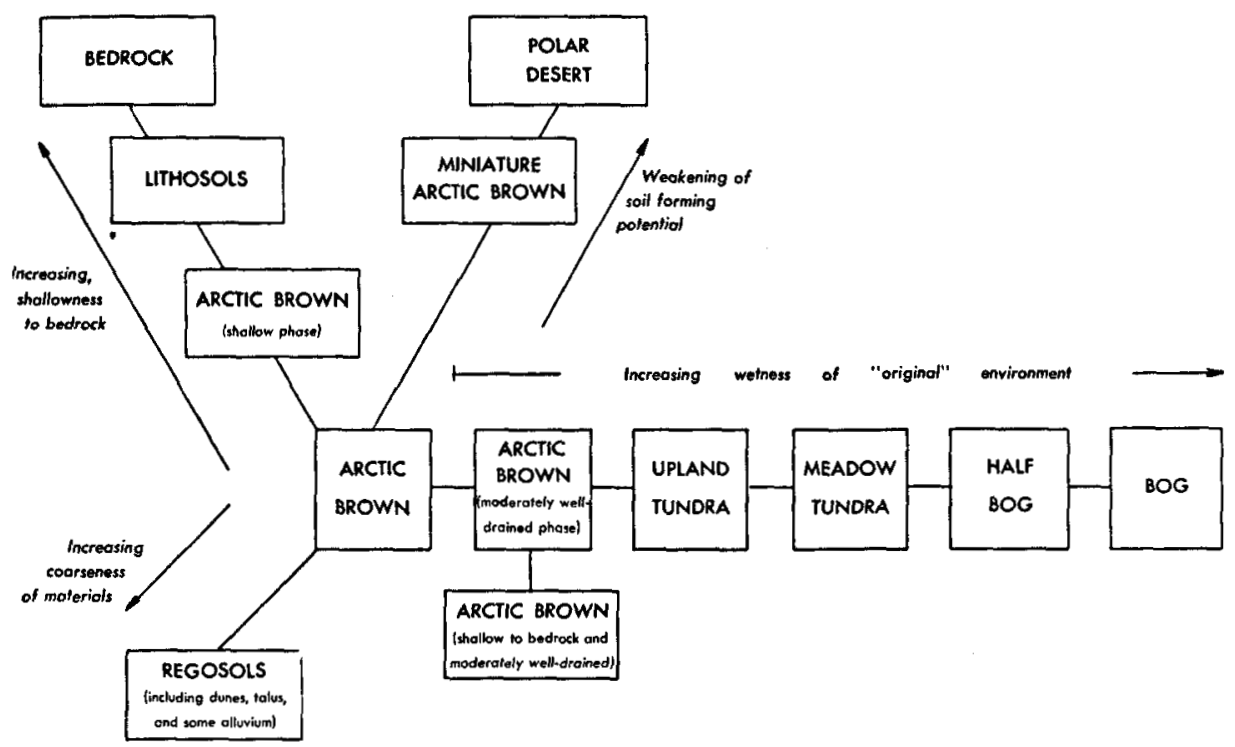

Fig. 6. The genetic soils of arctic Alaska can be arranged in the form of a sequence starting with the arctic brown and progressing through more poorly drained conditions to the bog soils. A sequence of soils is also present in the more shallow areas beginning with the arctic brown and continuing through progressively shallower soils to situations where bedrock is exposed at the surface. North of the arctic brown climatic optimum the soil process weakens and the solum becomes very shallow. Eventually the process reaches the "near zero potential" in the polar desert. When the mineral material becomes very coarse a normal profile may fail to develop, in which case the soil is included with

\section{Regosols.}
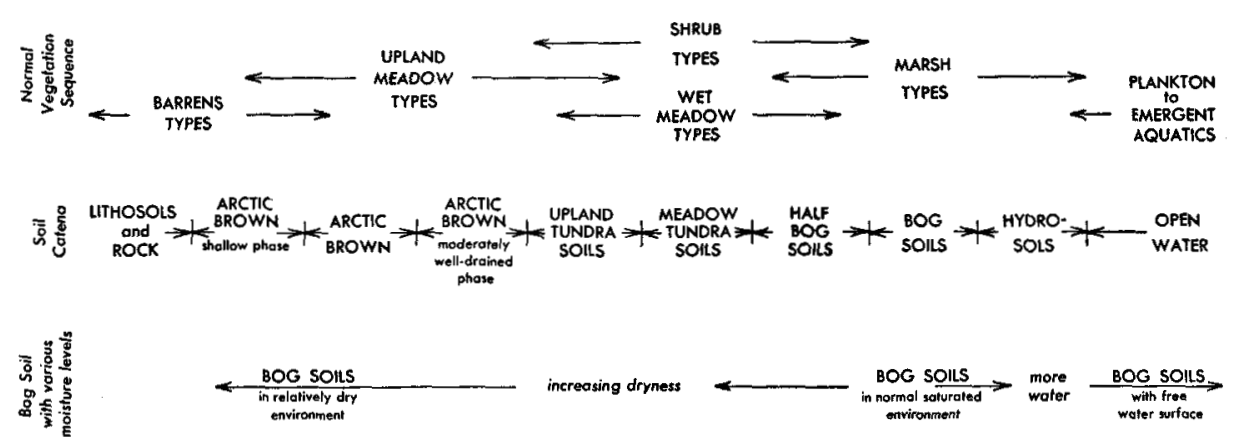

Fig. 7. Vegetation-soil relationships along a moisture gradient ranging from standing water on the right to extreme dry on the left. The soil drainage catena is in the middle row, whereas the same moisture gradient with bog soil is below. The species composition of the various vegetation types varies markedly with the moisture content of the bog soil. The shrub types and the Wet Meadow types occupy approximately the same range along the moisture gradient, the determining factors being snow depth, exposure to wind, soil aeration, summer temperatures, and others. 
Drury, 1956; Bliss and Cantlon, 1957; Cantlon and Gillis, 1957; Churchill and Hanson, 1958; among others). These patterns are due to several classes of micro-site differences but soil moisture during the growing season, and snow depth during the winter are the most frequent and conspicuous differences.

Non-correspondence of profile morphology and present site conditions. In arctic Alaska bog soils normally form under naturally poor drainage, and the usual vegetation is Marsh (Carex aquatilis ${ }^{1}, C$. rotundata, C. rariflora, Carex spp., Eriophorum angustifolium, E. scheuchzeri, Arctophila fulva, Dupontia fisheri, Hypnum spp., and Sphagnum spp., among others) or certain Meadow types (Sphagnum spp., Dicranum elongatum, and Aulocomnium, with Eriophorum vaginatum, Vaccinium vitis-idaea ssp. minus, and Rubus chamaemorus, among many others). Subsequent frost or geomorphic processes (polygonization, headward stream erosion, and lake drainage) may produce micro-relief features that in turn increase runoff and effectively reduce the moisture content of the upper soil layers (Fig. 8). On these better-drained bog soils vegetation becomes established that resembles communities normally found farther up the drainage catena. These are various Meadow types, ranging from Wet Meadow (Eriophorum vaginatum ssp. spissum, Carex bigelowii, Dicranum spp., Aulocomnium spp., Salix pulchra, Vaccinium vitis-idaea ssp. minus, Betula nana ssp. exilis, Ledum palustre ssp. decumbens, Cetraria spp., Cladonia spp., among others) to Dry Meadow (Dryas integrifolia, D. octopetala, Vaccinium vitis-idaea ssp. minus, Salix phlebophylla, and crustose lichens, among others). The more effective the drainage, the more pronounced the shift toward Dry Meadow, or on extreme convexities even to Barrens types with a sparse cover of lichens, mosses, Luzula confusa, and others. These latter communities may have many species in common with vegetation types normally associated with the well-drained mineral soils.

The creation of micro-relief features is somewhat analogous to the draining of bogs in more southerly areas by ditching or tile drains. In the temperate climates, however, profiles classed as well-drained usually have good drainage to a depth of 3 feet or more. The mesic species of the Arctic do not require such a great depth of well-drained soil, and adequate drainage and aeration to a depth of only a few inches is here sufficient to allow the more mesic communities of the Arctic to become established. The low rainfall, coupled with higher air speeds at ground level, favours xeric species on the pronounced convexities. These species are probably also favoured by the shallowness of the snow cover.

Just as there are conditions under which certain tundra and bog soils may exist in comparatively well-drained environments, so there are other conditions in which these soils, as based on profile morphology, appear to be in unusually wet environments (Fig. 9). It is not uncommon for a mineral soil to be completely covered with water throughout the growing season, a

1 Vascular plant nomenclature follows Hultén (1941-50). 
Figs. 8 and 9. Bog soils in two highly diverse environments near Barrow, Alaska.

Fig. 8. Bog soil in

a relatively well-drained environment. The vegetation is Upland Meadow and probably includes the mosses Ceratodon and Distichium, the lichens Cetraria spp., Cladonia spp., Stereocaulon and Thamnolia vermicularis and the vascular plants Luzula spp., Poa arctica, Vaccinium vitis-idaea, Salix rotundifolia, and Potentilla emarginata.
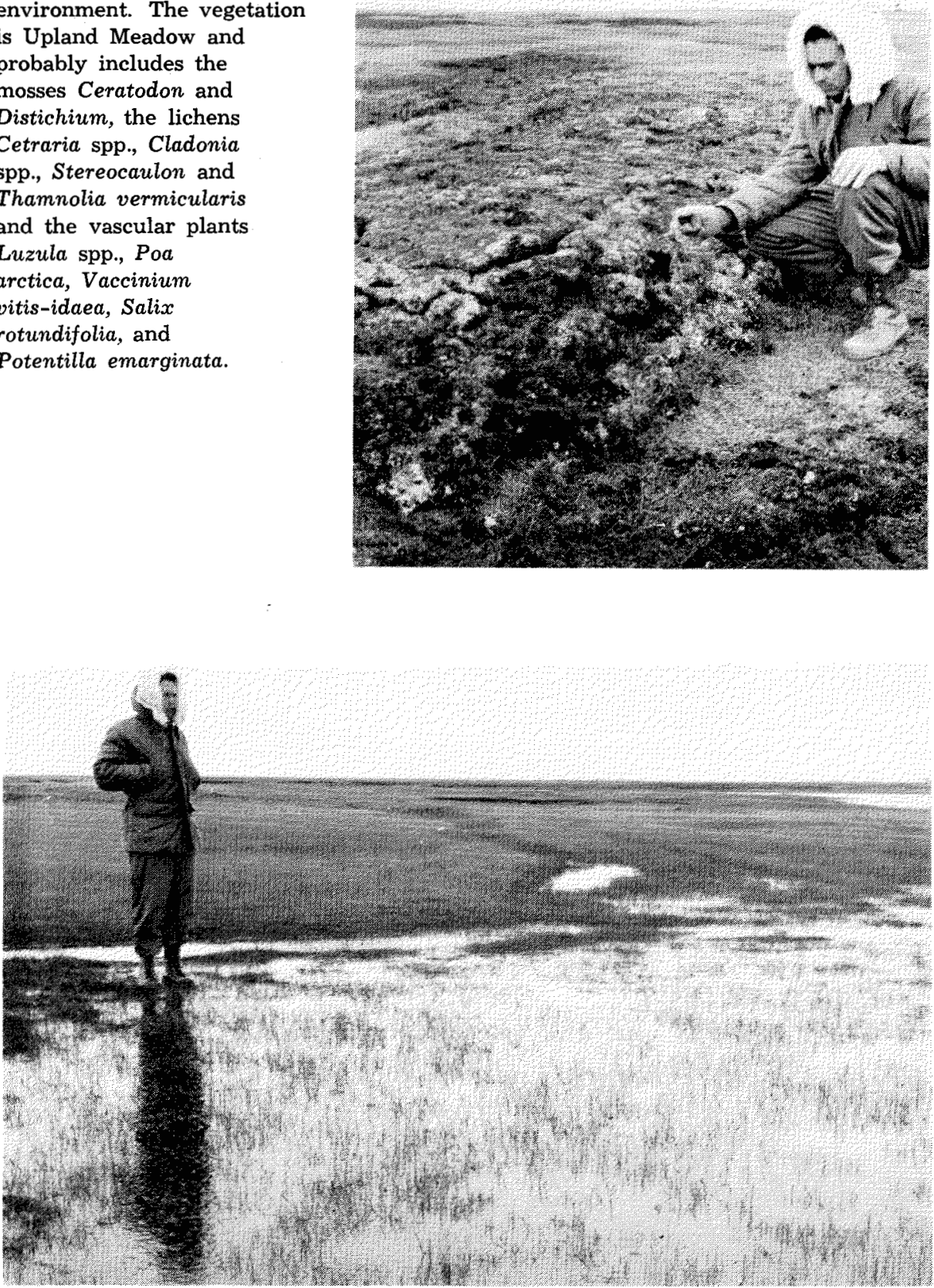

Fig. 9. Bog soil with Marsh vegetation consisting primarily of Arctophila fulva, Eriophorum spp., Carex aquatilis and Dupontia fisheri. The mosses Tomethypnum and Drepanocladus are also present. Unless the relative wetness of the site is considered, these two soil conditions (Fig. 8 and Fig. 9) would probably be classed as the same unit. 
condition favourable to the eventual formation of an organic soil. Apparently, this situation arises from formation of low-centre polygons, frost collapse, frost action in the soil, the element of time, and related factors, that cause a change in environment. Because of the short, cool growing season, however, organic matter accumulates at a very slow rate (Warren Wilson, 1957). Other situations in which the soils may be in a wetter environment than the profiles suggest are those where subsidence from thermokarst activity (Wallace, 1948; Hopkins, 1949) or stream meandering have occurred.

Normally the morphology of the soil profile is an expression of the combined factors of soil formation. If the environment changes, then the morphology should also change. Apparently, readjustment to the new environment takes place so slowly under arctic conditions that the higher water content of these mineral soils or the well-drained surface on bog soils are "semi-permanent" features of the profiles. Such lack of correspondence between the profile and present environment occurs widely and no better suggestion for their interpretation is at hand.

Soil variation and soil mapping problems. Drew (1957) discussed some of the problems involved and prepared a map of the soils of the Barrow area in northern Alaska. In flat, highly polygonized areas (Fig. 10), a high order of variation in micro-relief features influences the moisture content of the surface soil. The elevated portions of the polygons are comparatively dry, whereas the low portions of the polygonized areas are commonly covered with water during the summer months. Thus, within distances of a few feet, a wide spectrum of soil conditions and plant species is commonly found (Wiggins, 1951). In the highly polygonized areas it would be virtually impossible to delineate and describe even in broadest terms a profile per se unless an abnormally large scale was used.

Somewhat akin to the difficulties met with on poorly drained sites are those frequently encountered on the steeply sloping uplands. Here, although non-sorted polygons (Washburn, 1956) are feebly expressed and perhaps locally absent, another type of micro-topography occurs. This takes the form of small, oblong mounds, ranging from a few inches up to 2 feet in height and from 2 to 6 feet long, with their long axes frequently at right angles to the contour. Irregular trenches occur between, the width of which varies from a few inches to a few feet. The soil in the trenches has a somewhat thicker organic layer and is moist, whereas the convexities have a slightly thinner layer and are drier. If slope is not excessive the differences between the mounds and the trenches are small and the entire complex falls within the range of what can be classed as upland tundra or meadow tundra soils. The vegetation on the two kinds of micro-sites show a marked difference, however, giving rise to an intricate mosaic composed of two or more groups of species (basic units in the sense of Hopkins, 1957), but which in descriptions are lumped into one "community".

On steeper slopes the micro-relief is more pronounced and the differences in vegetation between convexities and trenches strain the single "community" designation. The soil, with its excessive number of mounds 


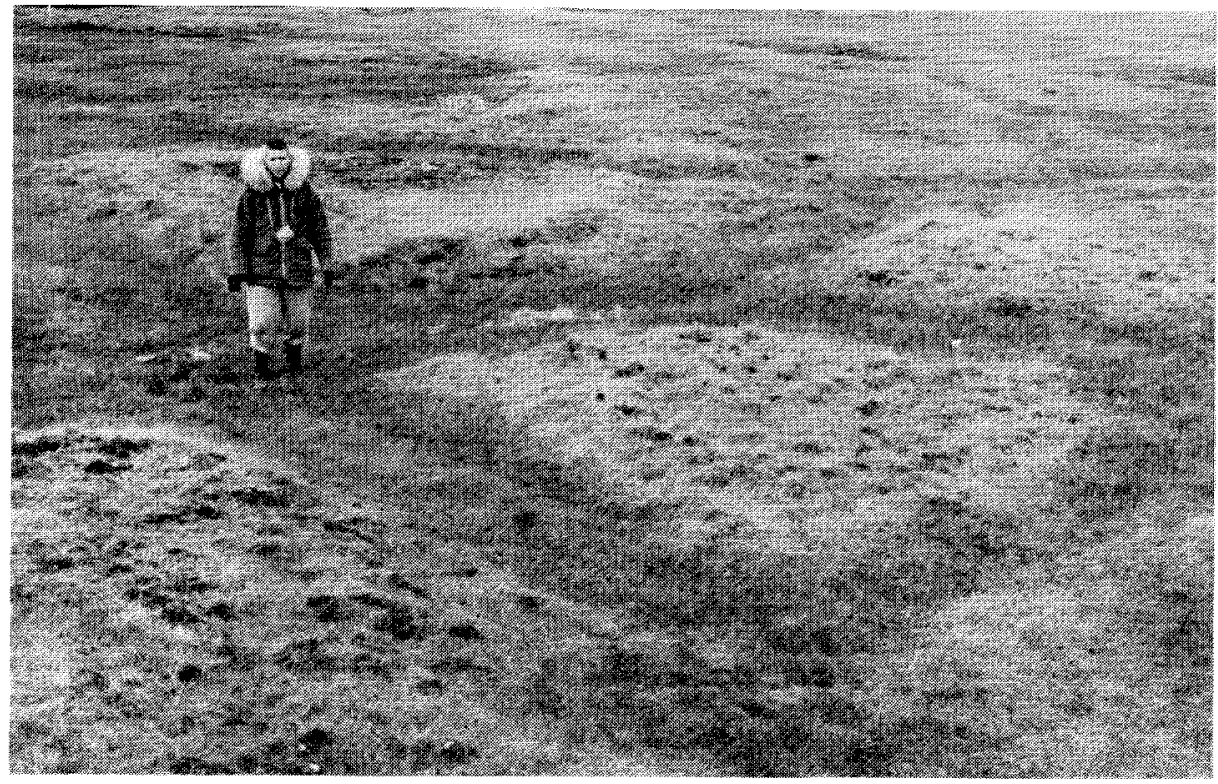

Fig. 10.

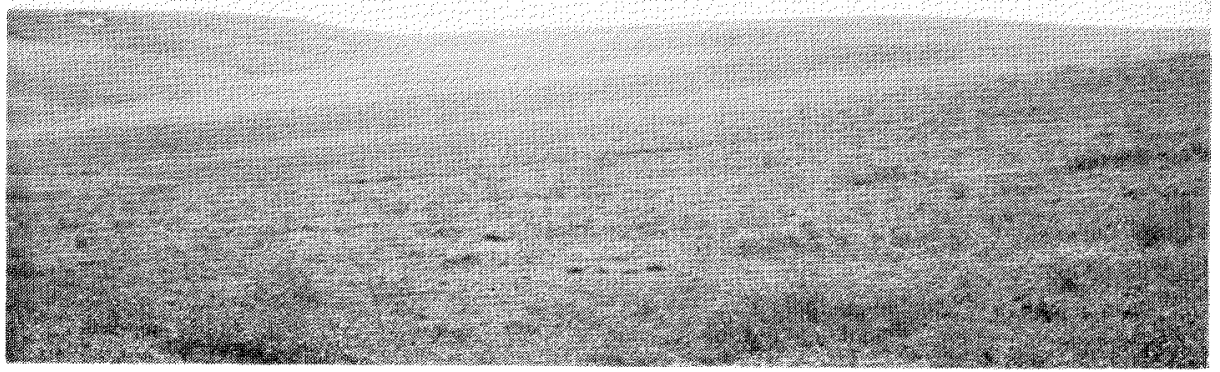

Fig. 11.

Figs. 10 and 11. Soil classification is more complicated in areas of polygonization than in the sloping areas of smooth relief. Fig. 10 shows a highly polygonized soil near Point Barrow. Fig. 11 shows rather smooth terrain features in the uplands near Umiat.

and solifluction lobes, also may exceed the range usually recognized in upland or meadow tundra soils. These soils, together with such local variants as extensive areas of frost boils and stone nets, might be given special status in the delineated soil unit nearest to it in the drainage catena. 
The authors believe that the soils in the arctic regions can be classified in somewhat the same manner as they are being classified in other climatic regions. In fact, delineating soil units on the well-drained sites in the Arctic is little different from doing so on their temperate region counterparts. The areas are large enough and vegetation types have a fair degree of indicator value on these sites. Delineating tundra soils on gently to steeply sloping areas, such as in Fig. 11, can be done with facility, although there is some irregularity in the profile morphology. However, on the steep solifluction slopes (Fig. 2) and on the flat, highly polygonized areas factors in addition to profile morphology should be considered. Perhaps the independent mapping of micro-relief characteristics as proposed by Drew (1957) would suffice. Another alternative would be to describe the pattern of the soil complex based on principles set forth by Veatch (1934).

\section{Summary}

The soils of arctic Alaska can be arranged in a drainage catena in the same manner as those of other climatic regions. Mature or zonal soils (arctic brown) may be said to form only under adequate internal drainage. Tundra soils would thus not be considered mature or zonal, instead they would be intrazonal (hydromorphic). The arctic brown and related soils with brown surface horizons, tundra soils, and bog with permafrost are northern extensions counterparts of podzol, humic glei, and bog soils, respectively.

Plant communities have been successfully correlated with soils on welldrained sites and on areas of shallow soils. Correlation between soils and vegetation on the tundra and bog soils, however, poses major problems. Non-correspondence of soil profile with current site conditions is widespread because of the lag in development processes. Vegetation reflects the changes somewhat earlier. If relative wetness of the site is considered together with the profile morphology a workable relationship between soils and plant communities generally exists; and if the nature of the cryopedologic features is mapped independently, suitable soil maps may be prepared.

Appreciation is expressed to R. B. Alderfer, F. E. Bear, F. H. Bormann, L. A. Douglas, J. V. Drew, J. J. Koranda, and R. E. Shanks, for important field discussions and critical examination of the manuscript. The earlier phases of our arctic investigations were supported by Boston University, Physical Research Laboratory.

These studies were aided by a contract between ONR, Department of the Navy, and the Arctic Institute of North America. Reproduction in whole or in part is permitted for any purpose of the United States government.

\section{References}

Bliss, L. C. and J. E. Cantlon. 1957. Succession on river alluvium in northern Alaska. Am. Midl. Nat. 58:452-69.

Cantlon, J. E. and W. T. Gillis. 1957. Arctic plants in relation to various relief features. Bull. Ecol. Soc. Am. 38:98-9. (Abstract of unpublished paper presented at A.A.A.S. meeting, Indianapolis, Dec., 1957.) 
Churchill, E. D. 1955. Phytosociological and environmental characteristics of plant communities in the Umiat region of Alaska. Ecology 36:606-27.

Churchill, E. D. and H. C. Hanson. 1958. The concept of climax in arctic and alpine vegetation. Bot. Rev. 24:127-91.

Drew, J. V. 1957. A pedologic study of arctic Coastal Plain soils near Point Barrow, Alaska. Unpublished Ph.D. Thesis, Rutgers University.

Drew, J. V. and J. C. F. Tedrow. 1957. Pedology of an arctic brown profile near Point Barrow, Alaska. Soil Sci. Soc. Am. Proc. 21:336-9.

Drury, Jr., W. H. 1956. Bog flats and physiographic processes in the upper Kuskokwim River region, Alaska. Contr. Gray Herb., Harvard Univ. 178:1-130.

Glinka, K. D. 1928. The great soil groups of the world and their development. (Translated by C. F. Marbut) Ann Arbor: Edwards Bros. pp. 235.

Gorodkov, B. N. 1939. Peculiarities of the arctic top soil. Isvestiya Gosudarstvennogo Geograficheskogo obshchestva 71 (10):1516-32.

Kellogg, C. E. and I. J. Nygard. 1951. Exploratory study of the principal soil groups of Alaska. U.S. Dept. Agr. Agricultural Monograph 7. pp. 138.

Hopkins, B. 1957. Pattern in the plant community. J. Ecol. 45:451-63.

Hopkins, D. M. 1949. Thaw lakes and thaw sinks in the Imuruk Lake area, Seward Peninsula, Alaska. J. Geol. 57:119-31.

Hultén, E. 1941-50. Flora of Alaska and Yukon, Parts I-X. Lunds Universitets Årsskrift, N.F., Vols. 37-46.

Leahey, A. 1949. Factors affecting the extent of arable lands and the nature of the soils in the Yukon Territory. Proc. 7th Pacific Sci. Congr. 6:16-20.

Marbut, C. F. 1927. A scheme for soil classification. Proc. 1st Int. Congr. Soil Sci. V. 4 Comm. V:1-31.

Margulis, H. 1954. Aux sources de la pédologie. Publication de l'école nationale supérieure agronomique de Toulouse, $\mathrm{pp} .85$.

Meinardus, W. 1930. Boden der kalten Region. In E. Blank (Editor) Handbuch der Bodenlehre. Vol. 3, pp. 550. Berlin: J. Springer.

Neustruev, S. S. 1927. Genesis of soils. Russian pedological investigations, Acad. of Sci. U.S.S.R., Leningrad, 1-98.

Robinson, G. W. 1949. Soils, their origin, constitution and classification. pp. 573. London: Thomas Murby and Co.

Sigafoos, R. S. 1952. Frost action as a primary physical factor in tundra plant communities. Ecology 33:480-7.

Sigafoos, R. D. and D. M. Hopkins. 1952. Soil instability on slopes in regions of perennially frozen ground. Frost action in soils: a Symposium. Highw. Res. B. Spec. Rep. 2, Natl. Res. Counc. Publ. 213, pp. 176-92.

Spetzman, L. A. 1951. Plant geography and ecology of the arctic slope of Alaska. Unpublished M.Sc. Thesis, Univ. of Minnesota.

Tedrow, J. C. F., J. V. Drew, D. E. Hill, and L. A. Douglas. 1958. Major genetic soils of the arctic slope of Alaska. J. Soil Sci. 9:33-45.

Tedrow, J. C. F. and D. E. Hill. 1955. Arctic brown soil. Soil Sci. 80:265-75.

Veatch, J. C. 1934. Classification of land on a geographic basis. Michigan Acad. of Sci., Arts, and Letters. Vol. 19:359-65.

Wallace, R. E. 1948. Cave-in lakes in the Nabesna, Chisana and Tanana river valleys, eastern Alaska. J. Geol. 56:171-81.

Warren Wilson J. 1957. Observations on the temperatures of arctic plants and their environment. J. Ecol. 45:499-531.

Washburn, A. L. 1956. Classification of patterned ground and review of suggested origins. Bull. Geol. Soc. Am. 87:823-66.

Wiggins, I. L. 1951. The distribution of vascular plants of polygonal ground near Point Barrow, Alaska. Contr. Dudley Herb., Nat. Hist. Mus., Stanford Univ., Calif. 4:41-56. 